\title{
Influence of Various Phosphate Fertilizers on Yields of Red Spanish Pineapples in Puerto Rico
}

\author{
George Samuels and Héctor Gandía-Díz $z^{1}$
}

\section{INTRODUCTION}

Pineapples have shown little ol no response to applications of phosphate fertilizer in Puerto Rico. Samuels, Landrau, and Alers-Alers ${ }^{2}$ found that no to small increases in yields of Red Spanish pineapple were obtained with phosphate used at rates up to 56 pounds of $\mathrm{P}_{2} \mathrm{O}_{5}$ per acre, and applied up to 4 months after planting. Yields were depressed when 84 and 112 pounds of $\mathrm{P}_{2} \mathrm{O}_{5}$ per acre were applied. The high-level phosphate additions served to hasten pineapple fruiting and produce more culls.

The source of phosphate commonly used in Puerto Rico at the time of the work by Samuels, Landrau, and Alers-Alers, and up until a few years ago, was simple superphosphate (20-percent $\mathrm{P}_{2} \mathrm{O}_{5}$ ). At present triple superphosphate (45-percent $\mathrm{P}_{2} \mathrm{O}_{5}$ ) is the primary phosphate source in Puerto Rico, with a small quantity of ammoniated superphosphate (16percent $\mathrm{P}_{2} \mathrm{O}_{5}$ ) also being used. Both commercial fertilizer manufacturers in the United States and the Tennessee Valley Authority have made available new sources of phosphate for fertilizer usage.

It was felt advisable to reconsider the influence of phosphate fertilizers on pineapple yields by testing these new sources of phosphate now available in the fertilizer market. This paper reports the results of an experiment on the plant and a ratoon crop of Red Spanish pineapples under various phosphate sources, conducted by the Agronomy and Horticulture Department of this Agricultural Experiment Station.

\section{PROCEDURE}

The Red Spanish variety of pineapple was planted on a Bayamón sandy clay at the Pineapple Farm, Manatí, of the Agricultural Experiment Station. The Bayamón sandy clay has a friable brownish-red, permeable, granular, acid surface soil (pH 4.3) underlain by a deep-red, slightly plastic, but permeable clay subsoil.

The field was treated twice prior to planting with a broadcast injection

1 Agronomist and Horticulturist, respectively, Agricultural Experiment Station, University of Puerto Rico, Río Piedras, P.R.

${ }^{2}$ Samuels, G., Landrau, P., Jr., and Alers-Alers, S., Influence of phosphate fertilizers on pineapple yields, J. Agr. Univ. P.R. 40 (4) 218-23, 1956. 
of DD mixture (dichloropropane and dichloropropene) to control nematodes, and with Aldrin to control white grubs and ants.

The plots consisted of two rows, 9 feet long; the plants were 15 inches apart in the row, 2 feet between rows, and 12 feet between row centers.

TABLE 1.-Influence of various phosphate sources on Red Spanish pineapple yields at Manalt, P.R., plant and ratoon crop, 1960-62

\begin{tabular}{|c|c|c|c|c|c|c|c|}
\hline \multirow{3}{*}{ Source of phosphatel } & \multirow{3}{*}{$\begin{array}{c}\text { Fertilizer } \\
\text { composition }\end{array}$} & \multicolumn{6}{|c|}{ Yield of Red Spanish pineapple for- } \\
\hline & & \multicolumn{3}{|c|}{ Plant crop } & \multicolumn{3}{|c|}{ Ratoon crop } \\
\hline & & $\begin{array}{l}\text { Per } \\
\text { acre }\end{array}$ & $\mid \begin{array}{c}\text { Mean } \\
\text { weeight } \\
\text { per } \\
\text { fruit }\end{array}$ & $\left|\begin{array}{c}\text { Amount } \\
\text { har- } \\
\text { vested }\end{array}\right|$ & $\begin{array}{l}\text { Per } \\
\text { acre }\end{array}$ & $\begin{array}{c}\text { Mean } \\
\text { weight } \\
\text { per } \\
\text { fruit }\end{array}$ & $\begin{array}{c}\text { Amount } \\
\text { har- } \\
\text { vested }\end{array}$ \\
\hline & Percent & Tons & Pounds & Percent & Tons & Pounds & Percent \\
\hline None & - & 19.2 & 4.50 & 99 & 17.5 & 3.77 & 96 \\
\hline Simple superphosphate & $0-20-0$ & 18.6 & 4.34 & 100 & 17.2 & 3.59 & 100 \\
\hline Triple superphosphate & $0-45-0$ & 18.6 & 4.51 & 96 & 16.8 & 3.50 & 100 \\
\hline Raw-rock phosphate & $0-32-0$ & 18.6 & 4.40 & 98 & 16.8 & 3.57 & 100 \\
\hline Ammonium metaphosphate & $16-72-0$ & 19.7 & 4.59 & 100 & 17.2 & 3.62 & 100 \\
\hline Diammonium phosphate & $20-52-0$ & 15.7 & 4.13 & 88 & 13.9 & 3.46 & 87 \\
\hline Calcium metaphosphate & $0-62-0$ & 18.1 & 4.30 & 98 & 17.0 & 3.62 & 96 \\
\hline Dicalcium metaphosphate & $0-48-0$ & 18.4 & 4.47 & 95 & 17.8 & 3.53 & 100 \\
\hline $\begin{array}{l}\text { Potassium calcium pyrophos- } \\
\text { phate }\end{array}$ & $0-42-25$ & 17.0 & 4.21 & 94 & 15.8 & 3.50 & 93 \\
\hline Potassium metaphosphate & $0-47-28$ & 17.0 & 4.17 & 95 & 15.5 & 3.47 & 93 \\
\hline $\begin{array}{l}\text { Simple superphosphate }+1 \\
\text { ton calcium carbonate }\end{array}$ & $0-20-0$ & 18.4 & 4.45 & 95 & 16.6 & 3.84 & 93 \\
\hline \multicolumn{8}{|l|}{$\begin{array}{l}\text { Least significant difference } \\
\text { needed between treatments } \\
\text { at: }\end{array}$} \\
\hline 5-percent level & & 2.45 & 0.32 & 15 & 2.29 & 0.30 & 14 \\
\hline 1-percent level & & 3.54 & .45 & - & 3.11 & .41 & - \\
\hline
\end{tabular}

${ }_{1}^{1}$ Nitrogen and potash supplied at rate of $400 \mathrm{lb}$. N per acre as ammonium sulfate, and $300 \mathrm{lb}$. per acre of $\mathrm{K}_{2} \mathrm{O}$ as potassium sulfate, both being applied 1/2 at planting and $1 / 27$ months later.

There were 8 plants per row, or 16 plants per plot. The experimental design was a rectangular lattice of 12 treatments replicated 6 times. Slips of the Red Spanish variety were planted from April 12 to 14, 1960, and harvested in June and July 1961, for the plant crop, and in May and June 1962, for the ratoon crop.

The treatments used are given in table 1 , and they consisted of various sources of phosphate fertilizers applied at the rate of 100 pounds of $\mathrm{P}_{2} \mathrm{O}_{5}$ per acre at time of planting. Nitrogen was supplied at the rate of 400 pounds 
$\mathrm{N}$ per acre as ammonium sulfate, and potassium at 300 pounds $\mathrm{K}_{2} \mathrm{O}$ per acre as potassium sulfate. The nitrogen and potash was applied one-half at planting and one-half 7 months later. No phosphates were applied for the ratoon crop, but nitrogen and potash were supplied at the rate of 267 pounds $\mathrm{N}$ and 200 pounds of $\mathrm{K}_{2} \mathrm{O}$ per acre.

\section{RESULTS AND DISCUSSION}

There were no significant increases in yield of Red Spanish pineapple for any of the phosphate sources used in either crop as compared with the no-phosphate treatment (table 1). Neither the formerly used simple superphosphate, 20-percent $\mathrm{P}_{2} \mathrm{O}_{5}$, the now-used triple superphosphate, 45percent $\mathrm{P}_{2} \mathrm{O}_{5}$, nor any of the newer phosphate sources increased yields of pineapples per acre, mean weight per fruit, or percentage of crop harvested as compared with no application of phosphate fertilizers.

Yields for both crops were significantly lowered over the no-phosphate treatment when diammonium phosphate (20-52-0) was used as a source of phosphate (table 1). The decrease in tons of fruit per acre was attributable to both a lowering of the mean weight per fruit, and of the quantity of fruit harvested. No reason can be given at present to explain why this particular phosphate source markedly reduced yields.

The mean fruit weight, but not yields per acre, was significantly reduced at the 5-percent level by the use of potassium metaphosphate (table 1). Another potassium-phosphate source, potassium calcium phosphate, also reduced weight per fruit. In this experiment the potassium in these compounds was augmented with potassium sulfate to give a rate of 300 pounds of $\mathrm{K}_{2} \mathrm{O}$ per acre for all treatments for the plant crop, and 200 pounds for the ratoon crop. This potash level is considered optimum for the Bayamón sandy clay.

Although the soil was quite acid, $\mathrm{pH} 4.3$, the use of lime did not increase yields over those where no lime was applied. Many of the new phosphate sources carry little or no calcuum. However, this did not influence yields since calcium did not appear to be a limiting factor.

It appears that no response was obtained to phosphate fertilizers for Red Spanish pineapples on a Bayamón sandy clay, despite the varied sources utilized. Research and field practices have shown before that little or no responses are obtained to phosphate fertilizers in pineapples in Puerto Rico.

\section{SUMMARY}

A Bayamón sandy clay was used to evaluate various phosphate sources for fertilizing Red Spanish pineapples. The phosphate sources utilized were simple superphosphate, triple superphosphate, raw-rock phosphate, am- 
monium metaphosphate, diammonium phosphate, calcium metaphosphate, dicalcium metaphosphate, potassium calcium pyrophosphate, and potassium metaphosphate. The results on a plant and a ratoon crop indicated that:

1. There were no significant increases in yield of Red Spanish pineapple for any of the phosphate sources used as compared to the no-phosphate treatment.

2. Yields were significantly lowered over the no-phosphate treatment when diammonium phosphate (20-52-0) was used as a source of phosphate.

3. Mean weight, but not total weight of fruit per acre, was significantly reduced over the no-phosphate treatment when potassium metaphosphate $(0-47-28)$ was used as a source of phosphate.

\section{RESUMEN}

A fin de evaluar varias fuentes de fosfato para el abonamiento de piñas se usó un suelo arcilloso-arenoso tipo Bayamón. Las fuentes de fosfato fueron los superfosfatos simples, superfosfatos triples, roca fosfatada triturada, metafosfato amónico, fosfato diamónico, metafosfato de calcio, metafosfato dicálcico, pirofosfato de calcio y potasio, y metafosfato de potasio. Los resultados de la primera cosecha y de la de retono subsiguiente indicaron que:

1. No hubo aumento significativo en el rendimiento de la Española Roja no importa la fuente de fosfato que se usó, al compararse con las siembras que no fueron tratadas con fosfato.

2. Cuando se usó el fosfato diamónico (20-52-0) como fuente de fosfato los rendimientos fueron significativamente más bajos al compararse con los de las siembras que no recibieron fosfato.

3. El promedio de peso por fruta, aunque no el peso total de la cosechà por cuerda, se redujo significativamente al compararse con la producción cuando se usó el metafosfato de potasio (0-47-28) como fuente de fosfato. 